\title{
Supply chain resilience in mindful humanitarian aid organizations: the role of big data analytics
}

\author{
Denis Dennehy \\ National University of Ireland Galway, Galway, Ireland \\ John Oredo \\ University of Nairobi, Nairobi, Kenya \\ Konstantina Spanaki \\ Audencia Business School, Nantes, France \\ Stella Despoudi \\ University of Western Macedonia, Grevena, Greece and \\ Aston University, Birmingham, UK, and \\ Mike Fitzgibbon \\ University College Cork, Cork, Ireland
}

Supply chain resilience

\begin{abstract}
Purpose - The purpose of this paper is to understand the nomological network of associations between collective mindfulness and big data analytics in fostering resilient humanitarian relief supply chains.

Design/methodology/approach - The authors conceptualize a research model grounded in literature and test the hypotheses using survey data collected from informants at humanitarian aid organizations in Africa and Europe.

Findings - The findings demonstrate that organizational mindfulness is key to enabling resilient humanitarian relief supply chains, as opposed to just big data analytics.

Originality/value - This is the first study to examine organizational mindfulness and big data analytics in the context of humanitarian relief supply chains.
\end{abstract}

Keywords Supply chain, Resilience, Big data analytics, Mindfulness, Humanitarian aid

Paper type Research paper

\section{Introduction}

The frequency and impact of natural and human-induced disasters has highlighted the critical need for resilient humanitarian aid operations during a crisis response (Flynn et al., 2020; de Camargo Fiorini et al., 2021; Queiroz et al., 2020). Natural disasters encompass geophysical (earthquake), hydrological (flood), meteorological (storm), climatological (drought) and biological (disease pandemics). Human-induced disasters include armed conflict, terrorism and hazardous accidents (World Health Organization, 2019). Disaster response is characterized as knowledge-intensive, time-sensitive, of short duration, high urgency and extreme uncertainty (Scholten et al., 2019a, b; Gutjahr and Nolz, 2016). Disaster response entails operations and supply chain management (OSCM) challenges such as planning, procurement, warehousing and rapid mobilization and deployment of supplies (Maghsoudi

(C) Denis Dennehy, John Oredo, Konstantina Spanaki, Stella Despoudi and Mike Fitzgibbon. Published by Emerald Publishing Limited. This article is published under the Creative Commons Attribution (CC BY 4.0) licence. Anyone may reproduce, distribute, translate and create derivative works of this article (for both commercial and non-commercial purposes), subject to full attribution to the original publication and authors. The full terms of this licence may be seen at http://creativecommons.org/licences/by/4.0/ legalcode

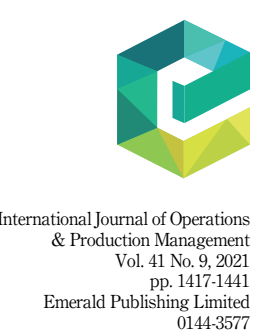

DOI 10.1108/JJOPM-12-2020-3577 
IJOPM 41,9

et al., 2018; Pedraza-Martinez and Van Wassenhove, 2016). Supply chains (SCs) in the context of disaster response are referred to as "humanitarian relief supply chains," which are arranged within a short timeframe by aid organizations (Ben-Tal et al., 2011; Van Wassenhove, 2006).

Emerging technologies are considered important in enabling an efficient and effective response to a disaster (Beydoun et al., 2018; Queiroz et al., 2021). However, there is a need to understand how emerging technologies can address the various challenges (delays, congestion) faced by humanitarian relief SCs (Rodríguez-Espíndola et al., 2020; Kumar and Singh, 2021).

Recent studies on emerging technologies such as blockchain (Fosso Wamba and Queiroz, 2020), artificial intelligence (Dwivedi et al., 2019), big data analytics (Kinra et al., 2020), internet of things (Boehmer et al., 2020) and three-dimensional (3D) printing (Roscoe et al., 2019) have demonstrated their important role in the context of commercial SCs. However, commercial SCs are usually proactive, whereas humanitarian relief SCs are primarily reactive (Dubey et al., 2021; Bhattacharya et al., 2014). Furthermore, demand and the likelihood of a disruption are relatively stable in commercial SCs (Stewart and Ivani, 2019).

In this study, these concerns are addressed by using organizational mindfulness (OMIN) as a theoretical frame to advance knowledge of SCRE in the context of humanitarian aid. Understanding the role of OMIN in this context is important, as mindfulness can address important organizational challenges such as attention overload and multi-tasking, as well as provide a foundation for better-quality information processing (Reb et al., 2020; Cheung et al., 2020).

Although a few studies (Papadopoulos et al., 2017; Dubey et al., 2021; Min, 2019) have examined the impact of emerging technologies on SCRE in the context of disaster response, there remains much scope for further research, specifically with a view to enhancing SCRE (Singh et al., 2018). SCRE is defined as "the adaptive capability of a SC to prepare for and/or respond to disruptions, to make a timely and cost-effective recovery, and therefore progress to a post-disruption state of operations - ideally, a better state than prior to the disruption" (Tukamuhabwa et al., 2015, p. 8).

Big data is an emerging technology that is viewed as a critical factor in generating new capabilities to optimize SCs (Queiroz and Telles, 2018; Frederico et al., 2019). The focus on big data analytics capabilities (BDACs) enables us to provide novel, yet important contributions to the OSCM, by better understanding SCRE in the context of humanitarian relief SC (Van der Vegt et al., 2015). However, finding optimal solutions for the management of humanitarian relief SCs should not be approached solely from the perspective of resource optimization (Abualkhair et al., 2020; Chandes and Paché, 2010). The effective management of humanitarian relief SCs is also dependent on the individuals involved in the crisis response initiative, also known as the "soft side" of organizations (Dubey and Gunasekaran, 2015). Yet, there is limited knowledge about the soft side of managing humanitarian relief SC (Dubey et al., 2021) since existing research largely focuses on the non-human aspects of disaster response operations (Siawsh et al., 2019). This study aims to address this gap by answering the following research question $(\mathrm{RQ})$ :

$R Q$. What is the role of $\mathrm{BDAC}$ and $\mathrm{OMIN}$ in developing resilient $\mathrm{SC}$ in a disaster response context?

This paper is organized as follows: a review of literature pertinent to this study is followed by the research methodology. Then, key findings and analysis lead to a discussion, the implications, future research and the conclusion.

\section{Theoretical background}

\subsection{Supply chain resilience}

SCRE is essentially a system's ability to have adaptable capabilities that can absorb interruptions (Folke, 2006; Tendall et al., 2015). SCRE capabilities include flexibility, 
redundancy, agility, efficiency, visibility, adaptation, anticipation, recovery, collaboration and security (Ivanov, 2020; Kamalahmadi and Parast, 2016). This study adopts the three main phases of disruption relevant to SCRE (readiness, responsiveness and recovery) (Ponomarov and Holcomb, 2009) and adds an additional phase (adaptive strategy), as suggested by Stone and Rahimifard (2018) to form the basis for grouping the core capabilities required in a resilient system.

The readiness phase refers to an organization's anticipation of a disruption either by preparing for it or by avoiding it (Fahimnia and Jabbarzadeh, 2016; Leat and Revoredo-Giha, 2013). This phase involves identifying and monitoring changes in the environment as well as those elements that need to be developed early to be utilized in other stages (Stone and Rahimifard, 2018). Flexibility is also required as it enhances resilience in the SC, which in turn enables an organization to respond and recover from disruptions (Stevenson and Spring, 2007).

The responsiveness phase refers to the pre-planned elements that mitigate the impact of a disruption, and at the same time, enable the system to remain functional (Fahimnia and Jabbarzadeh, 2016; Stone and Rahimifard, 2018). Information-sharing by partners across the $\mathrm{SC}$ is key to enabling the most effective response (Ivanov, 2020).

The recovery phase refers to both the repair of loss and the minimization of the time that it takes to return to the original or desired state (Fahimnia and Jabbarzadeh, 2016; Leat and Revoredo-Giha, 2013).

The adaptive strategy phase refers to the capability of a system to adjust operations in response to certain eventualities by using emergent technologies and learning from the disruption experience (Hohenstein et al., 2015).

\subsection{Supply chain resilience and the role of organizational mindfulness}

SCRE and crisis management initiatives have largely focused on recovery and adaptability in emergency situations while facing unpredicted challenges (Ambulkar et al., 2015; Craighead et al., 2007). Organizations that succeed in crisis management and resilience planning are viewed as "high reliability organizations" (HROs), a term that implies that organizations can successfully overcome turbulent conditions, with a minimum number of failures (Weick et al., 2008). Reliability in HROs reflects cognitive and behavioral attributes that can sustain resilience in times of crises (Weick et al., 1999; Weick and Sutcliffe, 2006). A shared characteristic of HROs is OMIN (Sutcliffe, 2011; Weick et al., 2008). Weick et al. (2008) argue that due to the criticality of errors and their consequences in HROs, learning by "trial and error" is intolerable and the reliability of HROs is grounded on highly standardized routines. The challenges facing humanitarian organizations can be considered within the everchanging processes following "trial-and-error" approaches and the limited standardization of fixed routines (Larson and Foropon, 2018). Therefore, the approaches to HROs cannot be applied in humanitarian organizations per se; they need to be tailored to the specifics of the humanitarian operations.

While HROs often imply a commercial venture that relies on a variety of tools for quality and process improvement, the humanitarian organizations hold the same goals as HROs but in a more fluid setting. What distinguishes a humanitarian organization from an $\mathrm{HRO}$ is the dynamic nature of humanitarian supply and demand, the changing stakeholders as well as a high level of uncertainty (Kovacs and Spens, 2007). Unlike commercial organizations, where the focus is primarily on "costs," humanitarian organizations focus on "time," due to life-anddeath disaster scenarios (Day et al., 2012). Essentially, SCs must be efficient, flexible and responsive to unpredictable events (Larson and Foropon, 2018).

Weick and Sutcliffe (2006) propose that OMIN is a combination of ongoing scrutiny of existing expectations with the capability to invent new expectations that make sense of unprecedented events. 
IJOPM 41,9

1420

A mindful organization advocates the "big picture" of operations and "act[s] thinkingly" by rewarding the reporting of failures, reducing assumptions and establishing measures to increase sensing capabilities of their employees (Weick et al., 2008). Situational awareness encompasses the cognition and comprehension of the current situation as well as its projection to the future, implying organizational learning behaviors (Levinthal and Rerup, 2006; Vogus and Sutcliffe, 2012). Weick et al. (1999) introduced the term "collective mindfulness" in relation to organizations and safety. In this study, mindfulness is explored in the context of humanitarian organizations since the effective adoption of its characteristics can lead to improved outcomes (Weick et al., 2005). Maitlis and Christianson (2014) highlight the necessity of mindfulness in organizations, as it allows resilience practices to emerge and creates a sense of urgency to take corrective actions in response to unexpected events. This approach marks the common ground shared by humanitarian organizations and HROs as persistence in the face of adversity leads to the resilience, which is a goal for both types of organizations (Ogliastri and Zuniga, 2016). Mindfulness in humanitarian organizations is defined in the following terms: situational awareness, development of an environment of "safety," sensitivity to operations, commitment to resilience and urgency for corrective actions, which are linked to mindfulness studies where organizations adopt technological interventions to remain resilient (Ramiller and Swanson, 2009).

\subsection{Supply chain resilience in mindful organizations enforcing big data capability}

As mindful organizations follow resilience practices for their SCs, they have to continuously reconfigure their resources in times of crises, to achieve the responsiveness and adaptability of the SC (Burnard et al., 2018; Weick et al., 2008). Mindful organizations focus on the practice of resilience to proactively prepare for disruptions through appropriate contingency planning (Mandal, 2019). SCRE provides the essential awareness in advance of a disaster situation through real-time communication and information-sharing (Fosso Wamba and Akter, 2019).

To build resilient SCs, organizations need to critically assess their technological capabilities to assist in the recovery of their SC from interruptions, as well as to cope with future interruptions (Dubey et al., 2021; Giannakis et al., 2019). Data-driven technological approaches, such as big data capability in organizations, could draw on unstructured data to explain disaster resilience (Dubey et al., 2021). Data-driven approaches are enforcing new organizational capabilities focusing on technology for collection and analysis of real-time data, termed as BDAC (Mikalef et al., 2019). BDAC is an emergent technological capability that refers to the organization's ability to capture and analyze data to generate insights by effectively deploying its resources to enable effective decision-making (Mikalef et al., 2020; Dubey et al., 2021).

\section{Hypothesis development and research model}

\subsection{Big data analytics capabilities and supply chain resilience}

The frequency and impact of disruptions to SCs has prompted researchers and practitioners to adopt an approach toward resilience (Remko, 2020). SCRE refers to how SC stakeholders contain and control a disturbance within the system, by developing strategies to mitigate its impacts (Kamalahmadi and Parast, 2016).

Several studies that investigated the link between big data analytics and SCM highlight the need for organizations to develop a data-driven culture (LaValle et al., 2011) and also note that big data analytics have a positive effect on SC performance (Trkman et al., 2010; Waller and Fawcett, 2013). However, the process through which organizations employ big data analytics in the wake of SC disruptions has not received adequate attention (Fan et al., 2016). We follow the recommendation that resilience studies should be grounded on dynamic 
capabilities (Teece et al., 1997), by adopting the concept of big data analytics capability to understand SCRE. Studies have shown that there is a complementary relationship between SC analytics and SC visibility and flexibility (Srinivasan and Swink, 2018), and that BDAC has a direct positive effect on SCRE (Dubey et al., 2021). Following on from this discussion, the following hypotheses are proposed:

H1. There is a positive relationship between BDACs and SCRE.

\subsection{Big data analytics capabilities and organizational mindfulness}

The multiplicity of disruptive events in the local and global SCs is forcing organizations to adopt resilient practices. Research shows that SC disruptions have significant economic impacts (Adobor McMullen, 2018) that can be very costly to organizations (Vanpoucke and Ellis, 2019). Studies also show that SC disruptions decrease firm stock prices by an average of 10\% (Hendricks and Singhal, 2005) and may take several years to recover (Wildgoose et al., 2012). To ensure SCRE, aid organizations should adopt the features of HROs as embodied in OMIN. The key features of OMIN include flexibility and commitment to resilience (Weick et al., 2008). Technology infrastructure is an integral part of core organizational capabilities for mindfulness and performance (Dernbecher and Beck, 2017). Redman (2014) demonstrates that BDAC enables the enhancement of adaptive capabilities to deal with uncertainty.

H2. There is a positive relationship between BDACs and OMIN.

\subsection{Big data analytics capabilities, organizational mindfulness and supply chain resilience}

$\mathrm{SC}$ are complex adaptive systems (CAS) that consist of several active agents that interact with each other according to a set of rules (Wycisk et al., 2008). Since CAS adapts by interacting with their environments and co-evolve to create dynamic emergent realities, SCRE has been described as an adaptive phenomenon (Shastri et al., 2014). Being an adaptive phenomenon, SCRE with features such as avoidance, redundancy, collaboration, agility and flexibility replicates the key principles of HRO (Sawyerr and Harrison, 2019). Highperforming organizations have been described as mindful organizations (Weick and Sutcliffe, 2006) as they operate under precariously complex conditions (Linnenluecke, 2017) but have the ability to avoid failures by achieving reliability through human processes and relationships (Weick and Sutcliffe, 2006). The pursuit of reliability and avoidance of accidents by HROs make them congruous to SCs that seek resilience through avoidance of disruptions and recovery and adaptability after disruptions (Sawyerr and Harrison, 2019).

H3. There is a positive relationship between OMIN and SCRE.

The adoption of emerging technologies like big data analytics can be prone to bandwagon effects, by adopting a technology due to pressure from other organizations that have already adopted it (Abrahamson and Bartner, 1990). To resist such bandwagon effects, organizations should assess technological innovations based on their usefulness to the organization's needs (Abrahamson, 1991). Mindful organizations are able to deal with the bandwagon phenomenon, especially in turbulent environments (Wolf et al., 2012). Mindfulness, as an organization's cognitive processes of revealing and redirecting new events and their erroneous consequences (Weick and Sutcliffe, 2006), is relevant in this study as aid organizations operating in turbulent times characterized by change, complexity and uncertainty (Dernbecher and Beck, 2017). OMIN enhances the recognition of organizational circumstances demanding an innovative approach and fostering the capabilities to effectively execute a timely response (Swanson and Ramiller, 2004). With regard to achieving time-sensitive organizational performance, there exists an association between mindful use of technological innovations and organizational resilience (Gardner et al., 2017).
Supply chain resilience 
IJOPM

41,9

1422
H4. OMIN mediates the relationship between BDACs and SCRE.

In this study, the conceptualization of BDAC is grounded on the dynamic capabilities view (Teece et al., 1997), which relates to actions and behaviors that are learned and institutionalized within organizations and are oriented toward their supplier relationships (Mitrega et al., 2017). These actions and behaviors are moderated by the organizational makeup, which consequently impacts organizational attitudes (Henneberg et al., 2010). This study adopts OMIN to represent the attitudes held by organizations regarding big data analytics. From a theoretical perspective, it has been demonstrated that mindfulness can moderate the relationship between theoretical constructs like BDAC and SCRE (Dernbecher and Beck, 2017). While in H4, OMIN has been theorized as mediating the relationship between BDAC and SCRE, we also explore a possible moderating role for OMIN. This attempt is motivated by the fact that the role of mindfulness is not adequately addressed in SCRE research. This is the view of Preacher et al. (2007), who asserted that in special cases, a variable can act both as a mediator and a moderator. This leads to the fifth hypothesis:

H5. OMIN moderates the relationship between BDACs and SCRE.

Drawing on the OMIN view of the firm, this study proposes the research model shown in Figure 1 . Note that $\mathrm{H} 4$ is derived indirectly through the mediation analysis procedure.

\section{Research methodology}

\subsection{Survey administration and data collection}

This study adopted the questionnaire-based survey method as it enables the identification of associations between variables and generalizability of findings (Pinsonneault and Kraemer, 1993). All constructs and respective items were operationalized on a five-point Likert scale, a well-accepted practice in empirical research (Kumar et al., 1993).

Following best practice, which recommends involving up to 50 people to test a survey (Sudman, 1983), a pretest was conducted with 50 humanitarian aid practitioners using Qualtrics. Qualtrics is a cloud-based platform for creating and distributing Web-based surveys that are General Data Protection Regulation-compliant. The pretest enabled us to examine survey design issues (Vanpoucke and Ellis, 2019). Several respondents known to the authors were contacted after completion of the pretest phase to discuss survey design issues.

To test the research model, a Web-based survey was sent to practitioners working with humanitarian aid organizations (Table 1) as the unit of analysis was at the organizational level. Author 1 had previously worked with both national and international nongovernmental organizations (NGOs) in Kenya for several years. Author 5 had over 15 years' experience with aid agencies throughout Africa and also lectures on the international

Figure 1.

Research model
BDA Capabilities

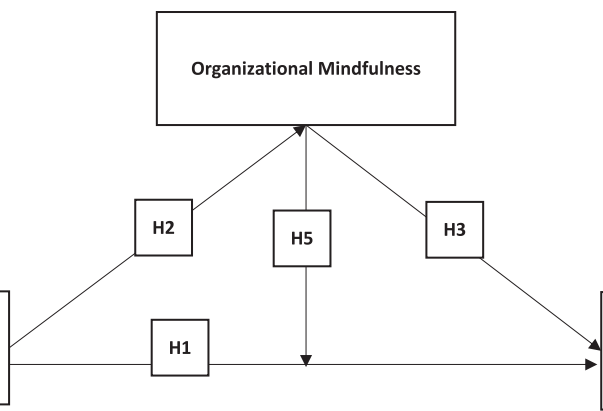

Supply Chain Resilience 
Factors

Gender

Female

Male

Years of experience in humanitarian aid

$1-5$ years

$6-10$ years

11-15 years

16-20 years

$21+$ years

Main place of work

Asia

Africa

Europe

North America

Highest qualification

$\mathrm{PhD}$

Postgraduate (master's, higher diploma)

Primary degree

Other (certificate, diploma, A-levels)

Respondent's position

Manager (regional, country, office, warehouse)

Field operative

IT and data analytics

Administrator

Public health care and social services

Medical (doctor, nurse)

Operations and supply chain logistics

Finance

C-level manager (CEO, director, founder)

Legal and public relations

Program evaluation and development

Security and maintenance

Type of organization

NGO

Registered charity

Government development department

Think tank/consultancy

\section{Headquarters}

Africa

Europe

North America

Years with current organization

$<5$ years

6-10 years

11-15 years

16-20 years

$20+$ years

Number of employees

$1-50$

51-100

101-500

501-1,000

$1,000+$
Sample $(n=135)$

Proportion $(\%)$

Supply chain resilience

58

42

78
57

57

9

8

21

28

7

5

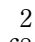

68

64

1

2

50

47

1

3

50

42

40

2

37

31

30

$38 \quad 28$

$18-13$

$16-12$

$14-10$

$12-9$

11

8

4

3

1423

94

43

8

4

65

62

8

46
6

34

25

16

23

25

37

Table 1.

$48 \quad 36$

$42-31$

$23-17$

9 
IJOPM 41,9 development degree program at a university. This experience provided access to NGOs (Concern, Goal, Trócaire) funded by Irish Aid, the Government of Ireland's international aid program, as well as access to alumni who had roles in organizations such as the United Nations. In addition, Author 2 lives in Kenya and has access to a network of aid organizations operating in East Africa. Individuals at these organizations were contacted by email informing them of the study's objective and offering a report of the aggregate findings, if requested. An email invitation with the survey link was then sent to individuals who agreed to participate; a follow-up email reminder was sent one week after the invitation. The data collection process took approximately ten weeks (September to mid-November 2020), and on average, the survey completion time was $9 \mathrm{~min}$. The final sample comprised 204 responses, of which 135 were complete and retained for analysis. Further, 69 responses were deemed not suitable for further analysis as 19 were incomplete and 50 were from the pretest.

\subsection{Measurements scales}

The scales used to measure the various constructs in this study were adapted from extant literature where they were previously tested. To ensure that the scales were relevant to the study, they were rephrased to fit the context of humanitarian relief SCs. The study variables, SCRE, OMIN and BDACs, were specified as first-order reflective constructs (cf. Urbach and Ahlemann, 2010). Reflective indicators are commonly used when the latent variables exist separately at a deeper level than its indicators. Modelling latent variables as reflective indicators is a common practice in organization-oriented studies (Vanpoucke and Ellis, 2019). Furthermore, constructs are not inherently formative or reflective in nature but are modeled based on the researcher's definition of the conceptual construct (MacKenzie et al., 2011). The mean of the survey items for each indicator was used as the final measure of the indicator. A Likert-type scale ranging from 1 (strongly disagree) to 5 (strongly agree) was used to capture the responses for the survey items. Table 2 is a summary of the study's items, their indicators, the survey items and the sources from which the measures were adapted.

\subsection{Non-response bias and common method bias}

The potential for non-response bias was assessed by comparing responses from early and late respondents on selected indicators from each latent variable following Armstrong and Overton (1977). It is assumed that late respondents are most similar to non-respondents because their replies required more nudging and took the longest time (Clottey and Grawe, 2014). Assessing non-response bias comparison of early and late respondents is widely used in OSCM research (Ateş and Memiş, 2021; Vanpoucke and Ellis, 2019). A sample of the first 50 early responders and the last 50 late responders was used for the comparison based on one indicator picked from every latent variable: OMIN2, BDAC2 and SCRE2. Mean differences for the three indicators were not significant $(p=0.625, p=0.449, p=0.465$, respectively), indicating that non-response bias was not a threat in this study.

To reduce the threat of common method bias, precautionary measures were taken during the survey design and administration. First, as mentioned previously, a pretest eliminated ambiguous terms in the survey. Second, anonymity of respondents was ensured to reduce desirability bias. Third, the order of the questionnaire items for the predictor and criterion variables were counterbalanced to mitigate the effects of priming as recommended by Podsakoff et al. (2003). To test for common method bias, we applied the Harman's singlefactor test (Podsakoff et al., 2003). When implemented using a factor-based partial least squares structural equation modeling (PLS-SEM) test (Kock, 2021), the average variance extracted (AVE) was 0.558 against the commonly suggested threshold of 0.5 . While the Harman's test indicated some levels of common method bias, the method is indicative and not confirmatory (Yu et al., 2019). 

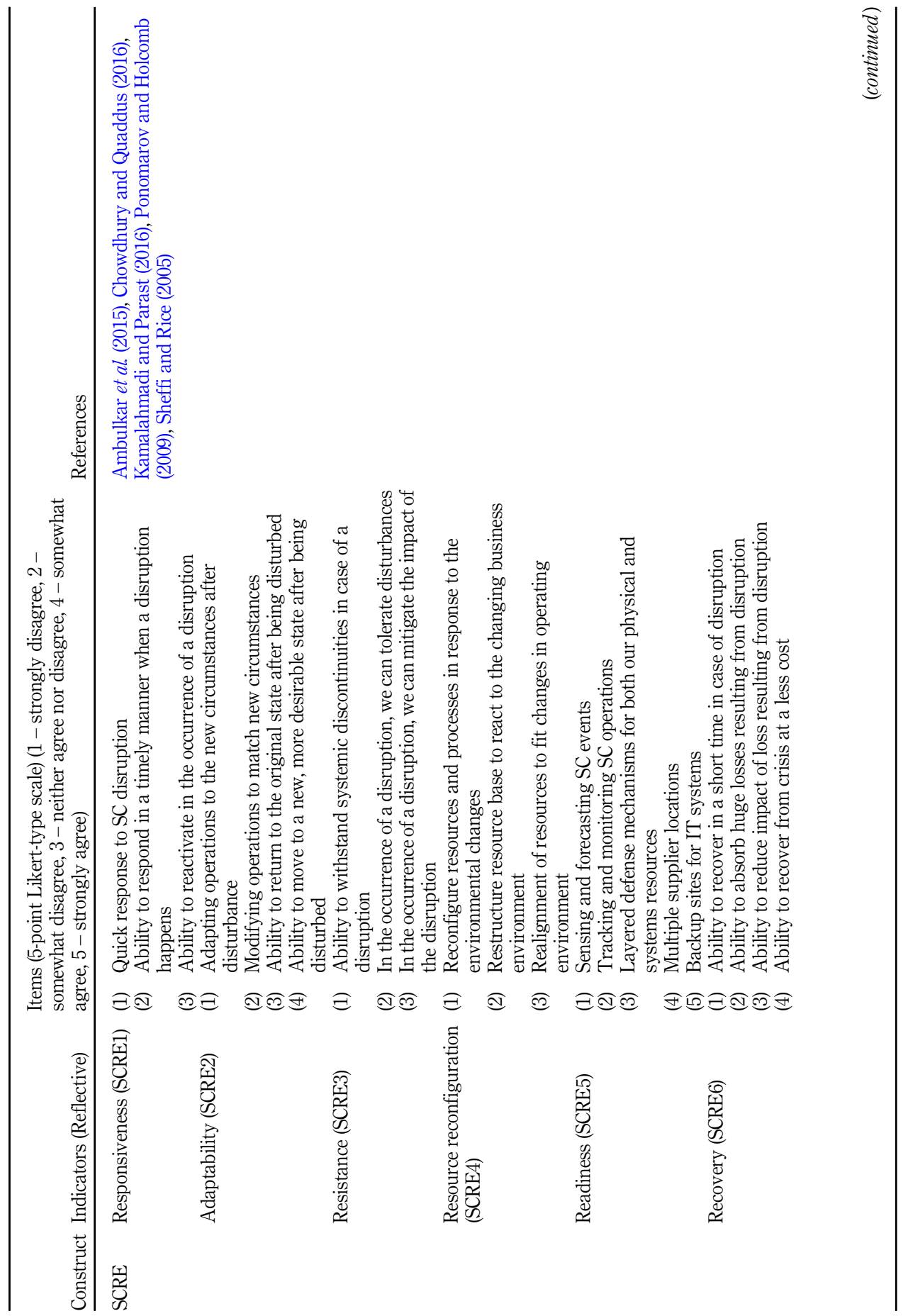

Supply chain resilience

1425

Table 2.

Summary of

constructs, their indicators and source 


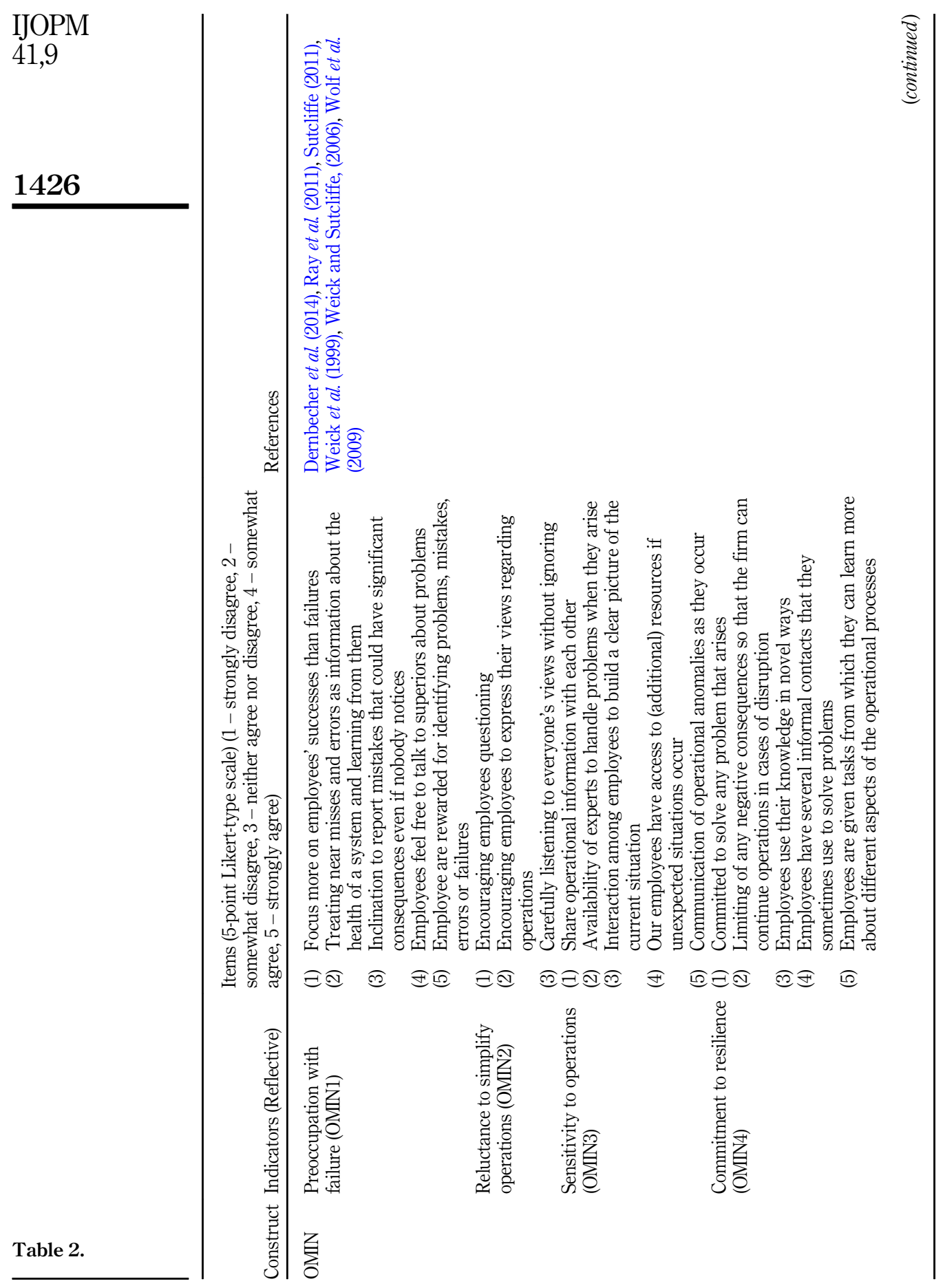




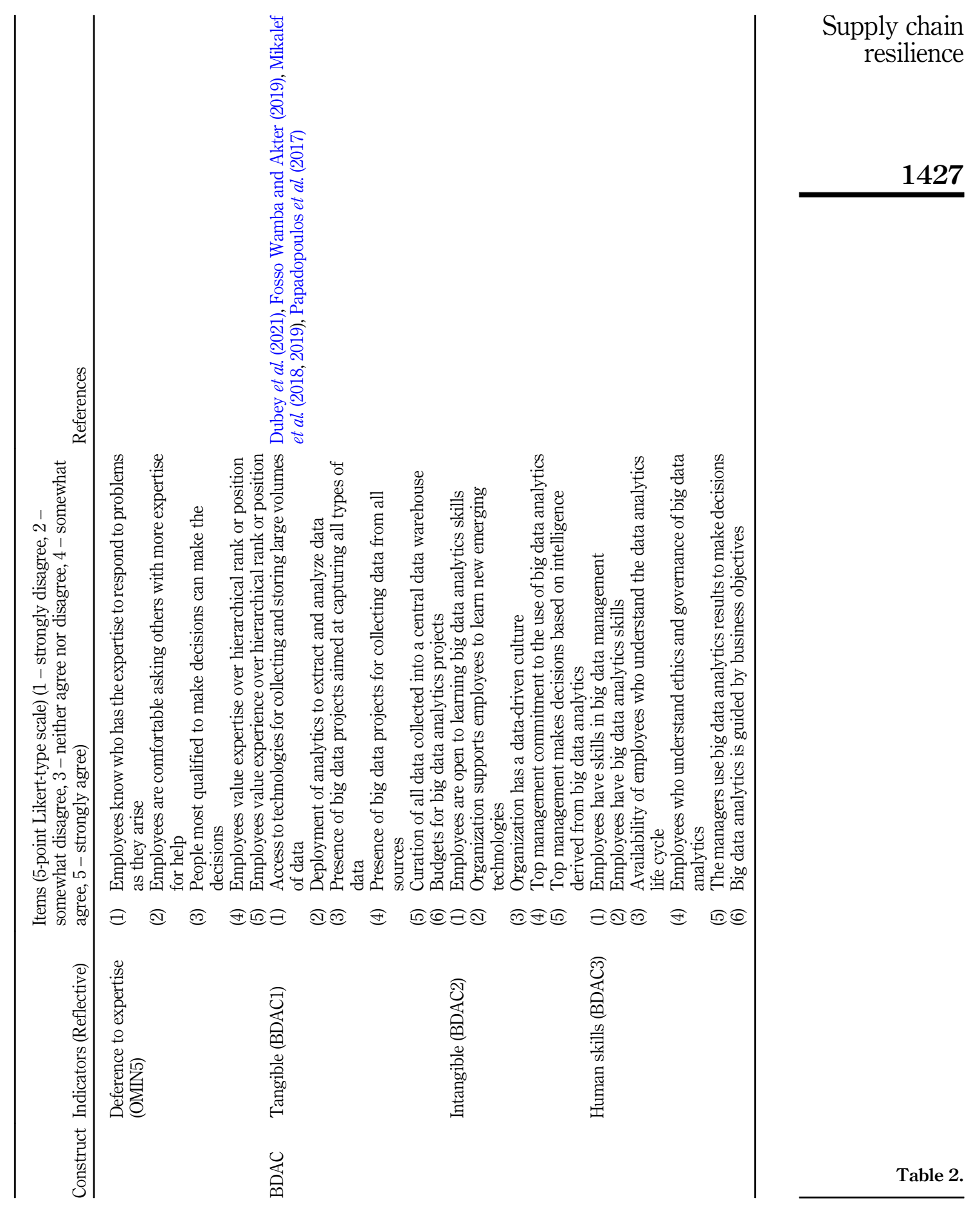


IJOPM 41,9

1428

\section{Data analysis}

\subsection{Measurement model evaluation}

The model was evaluated for reliability and validity before testing the hypotheses. For the construct to explain more than $50 \%$ of its indicators' variance, a loading of 0.708 is recommended to provide acceptable item reliability (Hair et al., 2019). Given that the latent variables of the study, which include BDAC, OMIN and SCRE, were measured using reflective indicators, the evaluation metrics recommended by Urbach and Ahlemann (2010) were conducted. Internal consistency reliability was evaluated using composite reliability (CR) and Cronbach's alpha (CA) with the threshold value of 0.700 and above, which indicates satisfactory reliability values (Hair et al.,2019). Convergent validity for each of the construct's measure was evaluated through the AVE. An acceptable value of AVE is 0.50 or higher, which indicates that the construct accounts for at least $50 \%$ of the variance of its items (Latan and Ghozali, 2012). The indicator reliability which measures how much of the indicators variance is explained by the corresponding latent variable was evaluated using cross loadings with a threshold value of 0.700 or slightly lower for exploratory studies (Chin, 1998). To ensure that no indicator inadvertently loaded highly on a different construct, crossloadings were obtained by correlating the component scores of each latent variable to all the other variables. The loading of each indicator is higher for its designated construct than for any other constructs and each of the construct loads highest within its own items as recommended by Latan and Ghozali (2012). The values for the cross-loadings, CA, CR and AVE are presented in Table 3.

To assess the discriminant validity, which is the extent to which a construct is empirically distinct from other constructs, two criteria were applied as recommended by Voorhees et al. (2016). The first one is the Fornell-Larcker (1981) criterion, which proposes that a factor's AVE should be higher than its squared correlations with all other factors in the

\begin{tabular}{|c|c|c|c|c|c|}
\hline & BDAC & $\mathrm{OMIN}$ & SCRE & $\mathrm{BDAC} * \mathrm{OMIN}$ & Fornell-Larcker \\
\hline \multirow{2}{*}{\multicolumn{5}{|c|}{$B D A C: C A=0.892, C R=0.933, A V E=0.822$}} & \multirow[t]{5}{*}{0.907} \\
\hline & & & & & \\
\hline BDAC1 & 0.910 & 0.526 & 0.695 & & \\
\hline BDAC2 & 0.899 & 0.644 & 0.722 & & \\
\hline BDAC3 & 0.912 & 0.488 & 0.728 & & \\
\hline \multicolumn{5}{|c|}{ OMIN: $C A=0.898, C R=0.925, A V E=0.711$} & \multirow[t]{7}{*}{0.613} \\
\hline OMIN & $(0.673)$ & & $(0.675)$ & $(0.573)$ & \\
\hline OMIN1 & 0.474 & 0.846 & 0.54 & & \\
\hline OMIN2 & 0.428 & 0.859 & 0.515 & & \\
\hline OMIN3 & 0.53 & 0.871 & 0.599 & & \\
\hline OMIN4 & 0.555 & 0.807 & 0.631 & & \\
\hline OMIN5 & 0.568 & 0.831 & 0.638 & & \\
\hline \multicolumn{5}{|c|}{ SCRE: $C A=0.914, C R=0.933, A V E=0.701$} & \multirow[t]{8}{*}{0.789} \\
\hline SCRE & $(0.864)$ & $(0.765)$ & & $(0.374)$ & \\
\hline SCRE1 & 0.685 & 0.585 & 0.871 & & \\
\hline SCRE2 & 0.638 & 0.691 & 0.877 & & \\
\hline SCRE3 & 0.466 & 0.496 & 0.711 & & \\
\hline SCRE4 & 0.677 & 0.593 & 0.819 & & \\
\hline SCRE5 & 0.814 & 0.597 & 0.897 & & \\
\hline SCRE6 & 0.635 & 0.547 & 0.836 & & \\
\hline \multicolumn{5}{|c|}{$B D A C^{*} O M I N: C A=1.00, C R=1.00, A V E=1.00$} & \multirow[t]{3}{*}{0.255} \\
\hline BDAC*OMIN & $(0.267)$ & & $(0.374)$ & & \\
\hline $\mathrm{BDAC} * \mathrm{OMIN}$ & -0.255 & -0.543 & -0.354 & & \\
\hline \multicolumn{6}{|c|}{ Note(s): HTMT measures in brackets } \\
\hline
\end{tabular}

$\begin{array}{llcc}\text { Table 3. } & \text { BDAC*OMIN: } C A=1.00, C R=1.00, A V E=1.00 & & 0.255 \\ \text { Reliability and } & \text { BDAC*OMIN } & (0.267) & (0.374) \\ \text { validity of the } & \text { BDAC*OMIN } & -0.255 \quad-0.543 & -0.354 \\ \text { measurement model } & \text { Note(s): HTMT measures in brackets } & \end{array}$ 
model. All the latent variables met the Fornell-Larcker criterion (Table 3). Although the Fornell-Larcker metric is largely used to assess discriminant validity, recent research shows that it does not perform very well, especially when the indicator loadings on a construct differ slightly (Henseler et al., 2015). As a result, Henseler (2017) proposed the heterotrait-monotrait ratio of correlations (HTMT), which estimates the upper boundary factor correlation and should be significantly smaller than 1 to discriminate between two factors. All factor correlations (Table 3) were below the threshold (0.900), as recommended by Franke and Sarstedt (2019).

\subsection{Structural model evaluation}

The model was evaluated through several metrics. The first standard evaluation criterion to be checked was collinearity. Collinearity was assessed through the variance inflation factor (VIF). The VIF (inner model) indicates how much of a construct's variance is explained by the other constructs and thus redundant. The VIF values for the inner paths were all less than 3 $(\mathrm{BDAC} \rightarrow \mathrm{SCRE}=1.625, \mathrm{BDAC} \rightarrow \mathrm{OMIN}=1.000, \mathrm{OMIN} \rightarrow \mathrm{SCRE}=2.155$ and $\mathrm{BDAC} * \mathrm{OMIN} \rightarrow \mathrm{SCRE}=1.439$ ), indicating that there were no collinearity issues among the constructs. Since collinearity was not an issue, we moved to examine the $R^{2}$ of the endogenous constructs. $R^{2}$ measures the variance that is accounted for in each of the endogenous constructs and is therefore considered a measure of the model's explanatory power (Hair et al., 2019). The rule of thumb considers $R^{2}$ values of 0.750 as substantial, 0.50 as moderate and values below 0.25 are considered weak (Henseler et al., 2015). The $R^{2}$ for OMIN was 0.376 , while that of SCRE was 0.698 , indicating weak and moderate explanatory power, respectively.

After checking the model's explanatory power through $R^{2}$, the statistical significance and relevance of the path coefficients were assessed. A path coefficient estimates the variability in an endogenous variable accounted for by a unit change in an exogenous variable, ceteris paribus. A path coefficient needs to be assessed for direction, magnitude, significance (Urbach and Ahlemann, 2010) and indirect effects such as mediation (Nitzl, 2016). The path coefficients of the model were greater than 0.100, except BDAC*OMIN (Table 4). Path coefficients that are greater than 1.00 are considered to be of substantial impact on the model (Urbach and Ahlemann, 2010). The significance of the path coefficients was examined through the bootstrapping algorithm (Hair et al., 2019) using 500 subsamples from the original dataset with 300 iterations to generate the $t$-statistics and $p$-values. In addition to assessing the $R^{2}$ value, the effect size, which evaluates the extent to which an omission of a particular exogenous construct leads to a change in $R^{2}$, was calculated using Cohen's $f^{2}$. To calculate the value of $f^{2}$, Cohen's (1988) guidelines for exogenous variables were used. Specifically, values of between 0.020 and 0.150 , between 0.150 and 0.350 , and those exceeding 0.350 indicate that an exogenous latent variable has a small, medium and large effect, respectively, on an endogenous latent variable. The Cohen's $f^{2}$ was estimated by means of bootstrapping and the results. The values of Cohen's $f^{2}$ were as follows: $\mathrm{BDAC} \rightarrow \mathrm{SCRE}=0.686, \mathrm{BDAC} \rightarrow \mathrm{OMIN}=0.602, \mathrm{OMIN} \rightarrow \mathrm{SCRE}=0.167$ and $\mathrm{BDAC}^{*} \mathrm{OMIN} \rightarrow \mathrm{SCRE}=0.002$. The results indicate that the exogenous variable $\mathrm{BDAC}$ had a

\begin{tabular}{|c|c|c|c|c|c|}
\hline$\#$ & Hypothesis & Path coefficient & $t$-statistic & $p$-values $($ alpha $<0.001)$ & Comment \\
\hline $\mathrm{H} 1$ & $\mathrm{BDAC} \rightarrow \mathrm{SCRE}$ & 0.580 & 10.663 & 0.000 & Supported \\
\hline $\mathrm{H} 2$ & $\mathrm{BDAC} \rightarrow \mathrm{OMIN}$ & 0.632 & 9.789 & 0.000 & Supported \\
\hline H3 & $\mathrm{OMIN} \rightarrow \mathrm{SCRE}$ & 0.330 & 4.778 & 0.000 & Supported \\
\hline $\mathrm{H} 4$ & $\mathrm{BDAC} \rightarrow \mathrm{OMIN} \rightarrow \mathrm{SCRE}$ & 0.202 & 3.941 & 0.000 & Supported \\
\hline H5 & $(\mathrm{BDAC} * \mathrm{OMIN}) \rightarrow \mathrm{SCRE}$ & -0.018 & 0.418 & 0.685 & Not supported \\
\hline
\end{tabular}

Supply chain resilience

1429 
IJOPM

41,9

1430

large effect on the endogenous variables SCRE and OMIN, while OMIN had a moderate effect on SCRE. The interaction effect (BDAC*OMIN) had a minimal effect on SCRE.

Another important structural model validity criterion that assesses the model's predictive accuracy is the $Q^{2}$ value, which is calculated by performing the Stone-Geisser's test through the blindfolding procedure. The blindfolding procedure removes single points in the data matrix and then imputs the removed points with the mean to estimate the model parameters (Sarstedt et al., 2014). Since $Q^{2}$ combines synthetic data points with the sample data points, it provides a hybrid prediction based on in-sampling and out-sampling. During blindfolding, omission distance was set to 7 as the model dataset had 135 observations $(n=135)$. This follows the recommendation of Hair et al. (2014, p. 167) that the omission distance (d) should be between 5 and 7 , provided that the quotient of the total number of observations $(n=135)$ and the omission distance $(n=7)$ are not an integer. The $Q^{2}$ values of the model's endogenous variables, $\mathrm{OMIN}=251$ and $\mathrm{SCRE}=479$, were above $0\left(Q^{2}>0\right)$ threshold, suggesting that they all had explanatory and predictive relevance (Hair et al., 2019).

In this study, the exogenous latent variables, BDAC and OMIN were used to explain the endogenous latent variable SCRE. In explanatory models, controlling for endogeneity is crucial when testing hypotheses (Papies et al., 2017). While endogeneity may have several causes, it generally stems from omitted variables that correlate with one or more independent variable(s) and the dependent variable(s) in the regression model (Rossi, 2014). Failing to account for endogeneity may lead to biased parameter estimates, which undermines the validity of the findings obtained from regression-type analysis of observed data (Sande and Ghosh, 2018). There are a number of approaches used to treat endogeneity problems such as the control variables approach (Germann et al., 2015) and the control function approach (De Blander, 2010). We tested for endogeneity on the latent variable SCRE because it had both direct $(\mathrm{BDAC}, \mathrm{OMIN})$ and an indirect predictor $(\mathrm{BDAC})$ using the instrumental variable approach. We adopted this approach as it is widely used in PLS-SEM (Sande and Ghosh, 2018). An interval variable, iv_SCRE, was created and added to the model as a predictor of SCRE to test for endogeneity through its path coefficient and significance (Kock, 2017) using WarpPLS 6.0. The path coefficient (iv_SCRE) was $B=0.02$ and $p=0.41$, showing that the endogeneity effect was minimal and non-significant.

\subsection{Hypothesis testing}

To assess the validity and reliability of the research model, PLS-SEM analysis was applied. PLS-SEM was chosen for this study for three pertinent reasons. First, it is considered an appropriate methodology for exploratory research and shares the modest distributional and sample size requirements of ordinary least squares regression (Hair et al., 2011). Second, PLSSEM is appropriate when estimating the relationships among latent variables (Urbach and Ahlemann, 2010). Specifically, the software package SmartPLS (v.3) was used to conduct all analyses. Finally, as the proposed research model builds more on exploratory theorybuilding, rather than theory-testing, PLS-SEM is a better alternative than covariance-based SEM (Hair et al., 2017).

The effect of BDAC on SCRE was positive and significant $(\beta=0.580, p<0.001)$. Therefore, $\mathrm{H} 1$ that BDAC influences SCRE is supported. The effect of BDAC on OMIN was positive and significant $(\beta=0.631, p<0.001)$, indicating that $\mathrm{H} 2$ is supported. The results for the estimation of the effect of OMIN on SCRE showed a positive and significant relationship $(\beta=0.330, p<0.001)$. H3 was, therefore, supported. The mediating role of OMIN on the relationship between BDAC and SCRE was estimated as $\beta=0.202, p<0.001$. This implies that the indirect role of OMIN as expressed in $\mathrm{H} 4(\mathrm{BDAC} \rightarrow \mathrm{OMIN} \rightarrow \mathrm{SCRE})$ was positive and significant and therefore supported. $\mathrm{H} 5$, which captured the interaction effect between OMIN and BDAC on SCRE, was negative and not significant. The small and insignificant effect of 
OMIN on the relationship between BDAC and SCRE may be attributed to the ceiling effect as there is already a strong and significant effect of BDAC on SCRE (Table 4).
Supply chain resilience

\section{Discussion, implications and future research}

Drawing on the contemporary literature, we frame both the theoretical and empirical contributions of this study. The most salient theoretical contribution of this research is the use of OMIN as a lens to study humanitarian relief SCs. This is an important contribution as studies linking OMIN and BDAC to SCM remain under-researched (Frederico et al., 2019). By investigating the moderating role of OMIN in SCRE, this study advances knowledge on the application of BDAC in the management of resilient SC (Bag et al., 2020; Khanra et al., 2020). Specifically, the effect of BDAC on OMIN is positive and significant, which reveals that BDAC is an antecedent of OMIN. This is an important revelation as previous studies have focused mainly on OMIN as a predictor but not on the antecedents of OMIN. Also, the moderating role of OMIN on the relationship between BDAC and SCRE is very small and not significant. This could be due to the fact that BDAC and OMIN explain almost $70 \%$ of SCRE.

OSCM studies (e.g. Dutta and Bose, 2015; Fossa Wamba et al., 2015) highlight the benefits of big data analytics (better decision-making, enhanced SC capabilities). Although emerging technologies have the potential to revolutionize OSCM (Roh et al., 2019), they remain understudied in the context of humanitarian relief SCs. By adopting an interdisciplinary perspective, this study supports research calls to break down existing walls between OSCM and other disciplines (Liberatore and Luo, 2010). By theorizing about the phenomena of $\mathrm{BDAC}$ in the context of humanitarian relief SCs, this research project makes important contributions to OSCM (Van der Vegt et al., 2015), specifically to the field of supply chain management, an emerging discipline (Harland et al., 2006).

As this study focuses on the intersection between BDAC and OMIN, in the context of resilient humanitarian relief SCs, it makes an empirical contribution (Han et al., 2020) as the findings demonstrate that OMIN is key to enabling SCRE, as opposed to just the BDAC itself (Reina and Kudesia, 2020). Specifically, the mediating role of OMIN is significant.

This study makes a methodological contribution by developing and testing the model in the context of humanitarian relief SCs, and therefore, it supports calls to move beyond traditional SCM (Scholten and Fynes, 2017). In doing so, we also extend the generalizability of OMIN and provide novel insights about SCRE that have not been reported previously. Specifically, BDAC had a strong effect on SCRE with an effect size ( $f$-squared) of 0.686 . This implies that BDAC had a strong explanatory power on SCRE compared to OMIN and BDAC*OMIN.

\subsection{Implications for research}

This study has implications for OSCM research. First, despite the differences between humanitarian and commercial SC, much can be learned by understanding how commercial SC techniques and research can be applied to humanitarian relief SC (Stewart and Ivanov, 2019). Second, while the outcome of this study reduces the gap between the understanding of SCM in academic literature and that in practice (Abualkhair et al., 2020; Remko, 2020), there remains a lack of scientific reasoning in disaster management when multiple disasters occur repeatedly "in the same space" (Alem et al., 2021).

Finally, the study provides empirical evidence to challenge the assumption that big data analytics will itself lead to a resilient humanitarian relief SC. This assertion leads to an important implication for OSCM research, as much of the claimed benefits about big data analytics lack theoretical validity as they have been provided by consultants (Gupta and George, 2016), who may be bias to the claims. Also, the study of SCs in the context of humanitarian relief operations is a relatively new field of research (Stewart and Ivanov, 2019). 
IJOPM 41,9

\subsection{Implications for practice}

The findings of this study present several interesting implications for OSCM and disaster response. First, this study highlights the value and importance of an organization's mindfulness, and therefore, managers need to develop and implement mindfulness strategies that can contribute to embedding an organizational resilient mindset to realize the potential benefits of big data analytics.

To develop BDAC, funding agencies need to allocate funding for sector-wide adoption of big data analytics. This may contradict the traditional funding model (Dennehy et al., 2013) where humanitarian organizations are constrained by cost minimization measures (Dubey et al., 2017). Another implication is the need to assess the time to acquire and develop key resources and the expected return on investment of big data analytics (Mikalef et al., 2020). Such an assessment is critical as there are claims that a high percentage of organizations have not realized the potential of their big data investment (Ross et al., 2013). Further, many of the individuals managing humanitarian relief SCs are not specialists in OSCM and therefore are not experts in the technologies that could be used to address SC disruptions (Ergun et al., 2009).

Finally, managers need to be aware that big data analytics is not a "silver bullet" to develop resilient SCs, and that fostering a data-driven mindful organizational culture is critical to generate value from big data analytics. The importance of organizational change has been highlighted by Vidgen et al. (2017), who provide guidelines on how to develop BDAC.

\subsection{Limitations and future research}

As with all research, however, we acknowledge this study has two limitations, which also offer directions for future research. The first relates to endogeneity (Guide and Ketokivi, 2015). We did test for endogeneity on the latent variable SCRE (Hair et al., 2019), and since the effect of endogeneity was minimal and non-significant, it was not necessary to control for it (Papies et al., 2017). The second limitation relates to survey-based research as the knowledgeintensive and time-sensitive activities of humanitarian aid may not always be captured (Scholten et al., 2019a, b). Future research could engage with a specific aid organization and seek organization-wide support to ensure that staff involved in disaster response initiatives complete the survey as this would improve internal validity and provide insights unique to the organization in terms of its state of mindfulness toward big data analytics. Future research could also focus on contextual factors such as the role of organizational culture (Dubey et al., 2020) and national culture (Gupta et al., 2019), as these have not been adequately explored in the context of humanitarian relief SCs and big data analytics. Despite these limitations, this study provides direction for future research in the OSCM field, which has been criticized for not engaging with emerging technologies (Vidgen et al., 2017; Mortenson et al., 2015).

\section{Conclusion}

This study was largely motivated by the urgent need to advance understanding about the role played by emerging technologies in developing and managing resilient humanitarian relief SCs. While valuable contributions have been made about big data analytics in commercial SCs, OSCM researchers have lagged behind in examining this aspect in humanitarian relief SCs. What studies do exist largely focus on the technology adoption, which has led to limited knowledge about the socio-technical aspects that can influence the successful use of big data analytics. This study uses OMIN and BDAC to advance knowledge to develop resilient humanitarian relief SCs. The findings demonstrate that OMIN is key to enabling resilient humanitarian relief SCs, as opposed to just big data analytics alone. In doing so, stakeholders involved in disaster response need to consider both the technical characteristics of big data analytics and the state of mindfulness of their organization. 


\section{References}

Abrahamson, E. (1991), "Managerial fads and fashions: the diffusion and rejection of innovations", The Academy of Management Review, Vol. 16 No. 3, pp. 586-612.

Abrahamson, E. and Bartner, L.R. (1990), "When do bandwagon diffusions roll? How far do they go? and when do they roll backwards? a computer simulation", Academy of Management Proceedings, Vol. 1990 No. 1, pp. 155-159, doi: 10.5465/ambpp.1990.4978478.

Abualkhair, H., Lodree, E.J. and Davis, L.B. (2020), "Managing volunteer convergence at disaster relief centers", International Journal of Production Economics, Vol. 220, p. 107399.

Adobor, H. and McMullen, R.S. (2018), "Supply chain resilience: a dynamic and multidimensional approach”, The International Journal of Logistics Management, Emerald Publishing Limited, Vol. 29 No. 4, pp. 1451-1471.

Alem, D., Bonilla-Londono, H.F., Barbosa-Povoa, A.P., Relvas, S., Ferreira, D. and Moreno, A. (2021), "Building disaster preparedness and response capacity in humanitarian supply chains using the Social Vulnerability Index”, European Journal of Operational Research, Vol. 292 No. 1, pp. 250-275.

Ambulkar, S., Blackhurst, J. and Grawe, S. (2015), "Firm's resilience to supply chain disruptions: scale development and empirical examination”, Journal of Operations Management, Vols 33-34, pp. 111-122.

Armstrong, J.S. and Overton, T.S. (1977), "Estimating nonresponse bias in mail surveys", Journal of Marketing Research, Vol. 14 No. 3, pp. 396-402.

Ateş, M.A. and Memiş, H. (2021), "Embracing supply base complexity: the contingency role of strategic purchasing", International Journal of Operations and Production Management, Vol. ahead-of-print No. ahead-of-print.

Bag, S., Gupta, S. and Luo, Z. (2020), "Examining the role of logistics 4.0 enabled dynamic capabilities on firm performance", The International Journal of Logistics Management, Vol. 31 No. 3, pp. 607-628.

Ben-Tal, A., Do Chung, B., Mandala, S.R. and Yao, T. (2011), "Robust optimization for emergency logistics planning: risk mitigation in humanitarian relief supply chains", Transportation Research Part B: Methodological, Vol. 45 No. 8, pp. 1177-1189.

Beydoun, G., Dascalu, S., Dominey-Howes, D. and Sheehan, A. (2018), "Disaster management and information systems: insights to emerging challenges", Information Systems Frontiers, Vol. 20, pp. 649-652.

Bhattacharya, S., Hasija, S. and Van Wassenhove, L.N. (2014), "Designing efficient infrastructural investment and asset transfer mechanisms in humanitarian supply chains", Production and Operations Management, Vol. 23 No. 9, pp. 1511-1521.

Boehmer, J.H., Shukla, M., Kapletia, D. and Tiwari, M.K. (2020), "The impact of the Internet of Things (IoT) on servitization: an exploration of changing supply relationships", Production Planning and Control, Vol. 31 Nos 2-3, pp. 203-219.

Burnard, K., Bhamra, R. and Tsinopoulos, C. (2018), "Building organizational resilience: four configurations", IEEE Transactions on Engineering Management, Vol. 65 No. 3, pp. 351-362.

Chandes, J. and Paché, G. (2010), "Investigating humanitarian logistics issues: from operations management to strategic action”, Journal of Manufacturing Technology Management, Vol. 21 No. 3, pp. 320-340.

Cheung, S.Y., Huang, E.G., Chang, S. and Wei, L. (2020), "Does being mindful make people more creative at work? The role of creative process engagement and perceived leader humility", Organizational Behavior and Human Decision Processes, Vol. 159, pp. 39-48.

Chin, W.W. (1998), "The partial least squares approach for structural equation modeling", Modern Methods for Business Research, Lawrence Erlbaum Associates Publishers, Mahwah, NJ, US, Vol. 295 No. 2, pp. 295-336.
Supply chain resilience

1433 
IJOPM 41,9

Chowdhury, M.M.H. and Quaddus, M. (2016), "Supply chain readiness, response and recovery for resilience”, Supply Chain Management: An International Journal, Vol. 21 No. 6, pp. 709-731, doi: 10.1108/SCM-12-2015-0463.

Clottey, T. and Grawe, S. (2014), "Non-response bias assessment in logistics survey research: use fewer tests?", International Journal of Physical Distribution and Logistics Management, Vol. 44 No. 5, pp. $412-426$.

Cohen, J. (1988), Statistical Power Analysis for the Behavioral Sciences, Routledge, Hillsdale, NJ.

Craighead, C.W., Blackhurst, J., Rungtusanatham, M.J. and Handfield, R.B. (2007), "The severity of supply chain disruptions: design characteristics and mitigation capabilities", Decision Sciences, Vol. 38 No. 1, pp. 131-156.

Day, J.M., Melnyk, S.A., Larson, P.D., Davis, E.W. and Whybark, D.C. (2012), "Humanitarian and disaster relief supply chains: a matter of life and death", Journal of Supply Chain Management, Vol. 48 No. 2, pp. 21-36.

De Blander, R. (2010), "A simple estimator for the correlated random coefficient model”, Economics Letters, Vol. 106 No. 3, pp. 158-161.

de Camargo Fiorini, P., Jabbour, C.J.C., de Sousa Jabbour, A.B.L. and Ramsden, G. (2021), "The human side of humanitarian supply chains: a research agenda and systematization framework", Annals of Operations Research, pp. 1-26.

Dennehy, D., Fitzgibbon, M. and Carton, F. (2013), “International development: exploring the gap between organisations' development policy and practice - a Southern perspective”, AI and Society, Springer-Verlag London, Vol. 29 No. 2, pp. 221-230.

Dernbecher, S. and Beck, R. (2017), "The concept of mindfulness in information systems research: a multi-dimensional analysis", European Journal of Information Systems, Vol. 26 No. 2, pp. 121-142.

Dernbecher, S., Risius, M. and Beck, R. (2014), "Bridging the gap-organizational mindfulness and mindful organizing in mobile work environments", Proceedings of ECIS, Tel Aviv, Isreal.

Dubey, R. and Gunasekaran, A. (2015), "Exploring soft TQM dimensions and their impact on firm performance: some exploratory empirical results", International Journal of Production Research, Vol. 53 No. 2, pp. 371-382.

Dubey, R., Gunasekaran, A., Papadopoulos, T., Childe, S.J., Shibin, K.T. and Wamba, S.F. (2017), "Sustainable supply chain management: framework and further research directions", Journal of Cleaner Production, Vol. 142, pp. 1119-1130.

Dubey, R., Gunasekaran, A., Bryde, D.J., Dwivedi, Y.K. and Papadopoulos, T. (2020), "Blockchain technology for enhancing swift-trust, collaboration and resilience within a humanitarian supply chain setting", International Journal of Production Research, Vol. 58 No. 11, pp. 3381-3398.

Dubey, R., Gunasekaran, A., Childe, S.J., Fosso Wamba, S., Roubaud, D. and Foropon, C. (2021), "Empirical investigation of data analytics capability and organizational flexibility as complements to supply chain resilience", International Journal of Production Research, Vol. 59 No. 1, pp. 110-128.

Dutta, D. and Bose, I. (2015), "Managing a big data project: the case of Ramco Cements Limited", International Journal of Production Economics, Vol. 165, pp. 293-306.

Dwivedi, Y.K., Hughes, L., Ismagilova, E., Aarts, G., Coombs, C., Crick, T., Duan, Y., Dwivedi, R., Edwards, J., Eirug, A. and Galanos, V. (2019), "Artificial Intelligence (AI): multidisciplinary perspectives on emerging challenges, opportunities, and agenda for research, practice and policy”, International Journal of Information Management, Vol. 57, p. 101994.

Ergun, O., Karakus, G., Keskinocak, P., Swann, J. and Villarreal, M. (2009), "Humanitarian supply chain management - an overview", Dagstuhl Seminar Proceedings 09261, available at: http:// drops.dagstuhl.de/opus/volltexte/2009/2181 (accessed 27 June 2021).

Fahimnia, B. and Jabbarzadeh, A. (2016), "Marrying supply chain sustainability and resilience: a match made in heaven", Transportation Research Part E: Logistics and Transportation Review, Vol. 91, pp. 306-324. 
Fan, H., Cheng, T.C.E., Li, G. and Lee, P.K.C. (2016), "The effectiveness of supply chain risk information processing capability: an information processing perspective", IEEE Transactions on Engineering Management, Vol. 63 No. 4, pp. 414-425.

Flynn, B., Cantor, D., Pagell, M., Dooley, K. and Azadegan, A. (2020), "Managing supply chains beyond covid-19: preparing for the next global mega-disruption", Journal of Supply Chain Management, Vol. 57 No. 1, pp. 3-6.

Folke, C. (2006), "Resilience: the emergence of a perspective for social-ecological systems analyses", Global Environmental Change, Vol. 16 No. 3, pp. 253-267.

Fornell, C. and Larcker, D.F. (1981), "Evaluating structural equation models with unobservable variables and measurement error", Journal of Marketing Research, Vol. 18 No. 1, pp. 39-50.

Fosso Wamba, S. and Akter, S. (2019), "Understanding supply chain analytics capabilities and agility for data-rich environments", International Journal of Operations and Production Management, Vol. 39 Nos 6-8, pp. 887-912.

Fosso Wamba, S. and Queiroz, M.M. (2020), "Blockchain in the operations and supply chain management: benefits, challenges and future research opportunities", International Journal of Information Management, Vol. 52, p. 102064.

Fosso Wamba, S.F., Akter, S., Edwards, A., Chopin, G. and Gnanzou, D. (2015), "How 'big data' can make big impact: findings from a systematic review and a longitudinal case study", International Journal of Production Economics, Vol. 165, pp. 234-246.

Franke, G. and Sarstedt, M. (2019), "Heuristics versus statistics in discriminant validity testing: a comparison of four procedures", Internet Research, Emerald Publishing Limited, Vol. 29 No. 3, pp. 430-447.

Frederico, G.F., Garza-Reyes, J.A., Anosike, A. and Kumar, V. (2019), "Supply chain 4.0: concepts, maturity and research agenda", Supply Chain Management: An International Journal, Vol. 25 No. 2, pp. 262-282.

Gardner, J.W., Boyer, K.K. and Ward, P.T. (2017), "Achieving time-sensitive organizational performance through mindful use of technologies and routines", Organization Science, Vol. 28 No. 6, pp. 1061-1079.

Germann, F., Ebbes, P. and Grewal, R. (2015), "The chief marketing officer matters!", Journal of Marketing, SAGE PublicationsSage CA: Los Angeles, CA, Vol. 79 No. 3, pp. 1-22.

Giannakis, M., Spanaki, K. and Dubey, R. (2019), "A cloud-based supply chain management system: effects on supply chain responsiveness", Journal of Enterprise Information Management, Vol. 32 No. 4, pp. 585-607.

Guide, V.D.R. Jr and Ketokivi, M. (2015), "Notes from the editors: redefining some methodological criteria for the journal”, Journal of Operations Management, Vol. 37 No. 1, pp. v-viii.

Gupta, M. and George, J.F. (2016), "Toward the development of a big data analytics capability", Information and Management, Vol. 53 No. 8, pp. 1049-1064.

Gupta, M., Esmaeilzadeh, P., Uz, I. and Tennant, V.M. (2019), “The effects of national cultural values on individuals' intention to participate in peer-to-peer sharing economy", Journal of Business Research, Vol. 97, pp. 20-29.

Gutjahr, W.J. and Nolz, P.C. (2016), "Multicriteria optimization in humanitarian aid", European Journal of Operational Research, Vol. 252 No. 2, pp. 351-366.

Hair, J.F., Ringle, C.M. and Sarstedt, M. (2011), "PLS-SEM: indeed a silver bullet", Journal of Marketing Theory and Practice, Vol. 19 No. 2, pp. 139-152, doi: 10.2753/MTP1069-6679190202.

Hair, J.F., Hult, G.T.M., Ringle, C.M., Sarstedt, M. and Thiele, K.O. (2017), "Mirror, mirror on the wall: a comparative evaluation of composite-based structural equation modeling methods", Journal of the Academy of Marketing Science, Vol. 45 No. 5, pp. 616-632.

Hair, J.F., Risher, J.J., Sarstedt, M. and Ringle, C.M. (2019), "When to use and how to report the results of PLS-SEM", European Business Review, Emerald Publishing Limited, Vol. 31 No. 1, pp. 2-24. 
IJOPM 41,9

Han, Y., Chong, W.-K. and Li, D. (2020), "A systematic literature review of the capabilities and performance metrics of supply chain resilience", International Journal of Production Research, Vol. 58 No. 15, pp. 4541-4566.

Harland, C.M., Lamming, R.C., Walker, H., Phillips, W.E., Caldwell, N.D., Johnsen, T.E., Knight, L.A. and Zheng, J. (2006), "Supply management: is it a discipline?", International Journal of Operations and Production Management, Vol. 26 No. 7, pp. 730-753.

Hendricks, K.B. and Singhal, V.R. (2005), "An empirical analysis of the effect of supply chain disruptions on long-run stock price performance and equity risk of the firm", Production and Operations Management, Vol. 4 No. 1, pp. 35-52.

Henneberg, S.C., Naudé, P. and Mouzas, S. (2010), "Sense-making and management in business networks-some observations, considerations, and a research agenda", Industrial Marketing Management, Vol. 39 No. 3, pp. 355-360.

Henseler, J. (2017), "Partial least squares path modeling”, in Leeflang, P., Wieringa, J.E., Bijmolt, T.H.A. and Pauwels, K.H. (Eds), Advanced Methods for Modeling Markets, Springer International Publishing.

Henseler, J., Ringle, C.M. and Sarstedt, M. (2015), “A new criterion for assessing discriminant validity in variance-based structural equation modeling", Journal of the Academy of Marketing Science, Vol. 43 No. 1, pp. 115-135.

Hohenstein, N.O., Feisel, E., Hartmann, E. and Giunipero, L. (2015), "Research on the phenomenon of supply chain resilience", International Journal of Physical Distribution and Logistics Management, Vol. 45 No. 1, pp. 90-117.

Ivanov, D. (2020), "Predicting the impacts of epidemic outbreaks on global supply chains: a simulation-based analysis on the coronavirus outbreak (COVID-19/SARS-CoV-2) case", Transportation Research Part E: Logistics and Transportation Review, Vol. 136, p. 101922.

Kamalahmadi, M. and Parast, M.M. (2016), "A review of the literature on the principles of enterprise and supply chain resilience: major findings and directions for future research", International Journal of Production Economics, Elsevier, Vol. 171 No. 1, pp. 116-133.

Khanra, S., Dhir, A. and Mäntymäki, M. (2020), "Big data analytics and enterprises: a bibliometric synthesis of the literature", Enterprise Information Systems, Vol. 14 No. 6, pp. 1-32.

Kinra, A., Hald, K.S., Mukkamala, R.R. and Vatrapu, R. (2020), “An unstructured big data approach for country logistics performance assessment in global supply chains", International Journal of Operations and Production Management, Vol. 40 No. 4, pp. 439-458.

Kock, N. (2017), "WarpPLS: endogeneity assessment and control", WarpPLS User Manual: Version 7.0, ScriptWarp Systems, Laredo, TX, p. 141, available at: https://www.scriptwarp.com/ warppls/UserManual_v_7_0.pdf (accessed 21 July 2021).

Kock, N. (2021), "Harman's single factor test in PLS-SEM: checking for common method bias", Data Analysis Perspectives Journal, Vol. 2 No. 2, pp. 1-6.

Kovács, G. and Spens, K.M. (2007), "Humanitarian logistics in disaster relief operations", International Journal of Physical Distribution and Logistics Management, Vol. 37 No. 2, pp. 99-114.

Kumar, P. and Singh, R.K. (2021), "Application of Industry 4.0 technologies for effective coordination in humanitarian supply chains: a strategic approach", Annals of Operations Research, Vol. 1 No. 1, pp. 1-33.

Kumar, N., Stern, L.W. and Anderson, J.C. (1993), "Conducting interorganizational research using key informants", Academy of Management Journal, Vol. 36 No. 6, pp. 1633-1651.

Larson, P.D. and Foropon, C. (2018), "Process improvement in humanitarian operations: an organisational theory perspective", International Journal of Production Research, Vol. 56 No. 21, pp. 6828-6841.

Latan, H. and Ghozali, I. (2012), Partial Least Square: Konsep, Teknik, dan Aplikasi SmartPLS 2.0 M3, Badan Penerbit Universitas Diponegoro, Semarang. 
LaValle, S., Lesser, E., Shockley, R., Hopkins, M.S. and Kruschwitz, N. (2011), "Big data, analytics and the path from insights to value", MIT Sloan Management Review, Vol. 52 No. 2, pp. 21-32.

Leat, P. and Revoredo-Giha, C. (2013), "Risk and resilience in agri-food supply chains: the case of the ASDA PorkLink supply chain in Scotland", Supply Chain Management, Vol. 18 No. 2, pp. 219-231.

Levinthal, D. and Rerup, C. (2006), "Crossing an apparent chasm: bridging mindful and less-mindful perspectives on organizational learning”, Organization Science, Vol. 17 No. 4, pp. 502-513.

Liberatore, M.J. and Luo, W. (2010), "The analytics movement: implications for operations research", Interfaces, Vol. 40 No. 4, pp. 313-324.

Linnenluecke, M.K. (2017), "Resilience in business and management research: a review of influential publications and a research agenda”, International Journal of Management Reviews, Vol. 19 No. 1, pp. 4-30.

MacKenzie, S., Podsakoff, P. and Podsakoff, N. (2011), "Construct measurement and validation procedures in MIS and behavioral research: integrating new and existing techniques", Management Information Systems Quarterly, Vol. 35 No. 2, pp. 293-334.

Maghsoudi, A., Zailani, S., Ramayah, T. and Pazirandeh, A. (2018), "Coordination of efforts in disaster relief supply chains: the moderating role of resource scarcity and redundancy", International Journal of Logistics-Research and Applications, Vol. 21, pp. 407-430.

Maitlis, S. and Christianson, M. (2014), "Sensemaking in organizations: taking stock and moving forward", Academy of Management Annals, Vol. 8 No. 1, pp. 57-125.

Mandal, S. (2019), "The influence of big data analytics management capabilities on supply chain preparedness, alertness and agility: an empirical investigation”, Information Technology and People, Vol. 32 No. 2, pp. 297-318.

Mikalef, P., Pappas, I.O., Krogstie, J. and Giannakos, M. (2018), "Big data analytics capabilities: a systematic literature review and research agenda", Information Systems and E-Business Management, Vol. 6 No. 3, pp. 547-578.

Mikalef, P., Boura, M., Lekakos, G. and Krogstie, J. (2019), "Big data analytics capabilities and innovation: the mediating role of dynamic capabilities and moderating effect of the environment", British Journal of Management, Vol. 30 No. 2, pp. 272-298.

Mikalef, P., Krogstie, J., Pappas, I.O. and Pavlou, P. (2020), "Exploring the relationship between big data analytics capability and competitive performance: the mediating roles of dynamic and operational capabilities", Information and Management, Vol. 57 No. 2, p. 103169.

Min, H. (2019), "Blockchain technology for enhancing supply chain resilience", Business Horizons, Vol. 62 No. 1, pp. 35-45.

Mitrega, M., Forkmann, S., Zaefarian, G. and Henneberg, S.C. (2017), "Networking capability in supplier relationships and its impact on product innovation and firm performance", International Journal of Operations and Production Management, Vol. 37 No. 5, pp. 577-606.

Mortenson, M.J., Doherty, N.F. and Robinson, S. (2015), "Operational research from Taylorism to Terabytes: a research agenda for the analytics age", European Journal of Operational Research, Vol. 241 No. 3, pp. 583-595.

Nitzl, C. (2016), "The use of partial least squares structural equation modelling (PLS-SEM) in management accounting research: directions for future theory development”, Journal of Accounting Literature, Vol. 37, pp. 19-35.

Ogliastri, E. and Zúñiga, R. (2016), "An introduction to mindfulness and sensemaking by highly reliable organizations in Latin America", Journal of Business Research, Vol. 69 No. 10, pp. 4429-4434.

Papadopoulos, T., Gunasekaran, A., Dubey, R., Altay, N., Childe, S.J. and Fosso Wamba, S. (2017), "The role of Big Data in explaining disaster resilience in supply chains for sustainability", Journal of Cleaner Production, Vol. 142, pp. 1108-1118.

Supply chain resilience 
IJOPM 41,9

Papies, D., Ebbes, P. and Van Heerde, H.J. (2017), “Addressing endogeneity in marketing models”, in Leeflang, P.S.H., Wieringa, J.E., Bijmolt, T.H.A. and Pauwels, K.H. (Eds), Advanced Methods for Modeling Markets, Springer International Publishing, Cham, pp. 581-627.

Pedraza-Martinez, A. and Van Wassenhove, L. (2016), "Empirically grounded research in humanitarian operations management: the way forward", Journal of Operations Management, Vol. 45, pp. 1-10.

Pinsonneault, A. and Kraemer, K. (1993), "Survey research methodology in management information systems: an assessment", Journal of Management Information Systems, Vol. 10 No. 2, pp. 75-105.

Podsakoff, P.M., MacKenzie, S.B., Lee, J.Y. and Podsakoff, N.P. (2003), "Common method biases in behavioral research: a critical review of the literature and recommended remedies", The Journal of Applied Psychology, Vol. 88 No. 5, pp. 879-903.

Ponomarov, S.Y. and Holcomb, M.C. (2009), "Understanding the concept of supply chain resilience", The International Journal of Logistics Management, Vol. 20 No. 1, pp. 124-143.

Preacher, K.J., Rucker, D.D. and Hayes, A.F. (2007), “Addressing moderated mediation hypotheses: theory, methods, and prescriptions", Multivariate Behavioral Research, Vol. 42 No. 1, pp. 185-227.

Queiroz, M.M. and Telles, R. (2018), "Big data analytics in supply chain and logistics: an empirical approach", The International Journal of Logistics Management, Vol. 29 No. 2, pp. 767-783.

Queiroz, M.M., Ivanov, D., Dolgui, A. and Fosso Wamba, S. (2020), "Impacts of epidemic outbreaks on supply chains: mapping a research agenda amid the COVID-19 pandemic through a structured literature review", Annals of Operations Research, pp. 1-38.

Queiroz, M.M., Pereira, S.C.F., Telles, R. and Machado, M.C. (2021), "Industry 4.0 and digital supply chain capabilities: a framework for understanding digitalisation challenges and opportunities", Benchmarking: An International Journal, Vol. 28 No. 5, pp. 1761-1782.

Ramiller, N.C. and Swanson, E.B. (2009), "Mindfulness routines for innovating with information technology”, Journal of Decision Systems, Vol. 18 No. 1, pp. 13-26.

Ray, J., Baker, L. and Lowman, A. (2011), “Organizational mindfulness in business schools”, Academy of Management Learning and Education, Vol. 10 No. 2, p. 188.

Reb, J., Allen, T. and Vogus, T.J. (2020), "Mindfulness arrives at work: deepening our understanding of mindfulness in organizations", Vol. 159, pp. 1-7.

Redman, C.L. (2014), "Should sustainability and resilience be combined or remain distinct pursuits?", Ecology and Society, Vol. 19 No. 2.

Reina, C. and Kudesia, R. (2020), "Wherever you go, there you become: how mindfulness arises in everyday situations", Organizational Behavior and Human Decision Processes, Vol. 159, pp. 78-96.

Remko, v.H. (2020), "Research opportunities for a more resilient post-COVID-19 supply chain - closing the gap between research findings and industry practice", International Journal of Operations and Production Management, Vol. 40 No. 4, pp. 341-355.

Rodríguez-Espíndola, O., Chowdhury, S., Beltagui, A. and Albores, P. (2020), "The potential of emergent disruptive technologies for humanitarian supply chains: the integration of blockchain, Artificial Intelligence and 3D printing”, International Journal of Production Research, Vol. 58 No. 15, pp. 4610-4630.

Roh, Y., Heo, G. and Whang, S.E. (2019), "A survey on data collection for machine learning: a big dataai integration perspective", IEEE Transactions on Knowledge and Data Engineering, Vol. 33 No. 4, pp. 1328-1347.

Roscoe, S., Cousins, P. and Handfield, R. (2019), "The microfoundations of an operational capability in digital manufacturing ?", Journal of Operations Management, Vol. 65 No. 8, pp. 774-793.

Ross, J.W., Beath, C.M. and Quaadgras, A. (2013), "You may not need big data after all", Harvard Business Review, Vol. 91 No. 12, p. 90. 
Rossi, P.E. (2014), "Even the rich can make themselves poor: a critical examination of IV methods in marketing applications", Marketing Science, INFORMS, Vol. 33 No. 5, pp. 655-672.

Sande, J.B. and Ghosh, M. (2018), "Endogeneity in survey research”, International Journal of Research in Marketing, Vol. 35 No. 2, pp. 185-204.

Sarstedt, M., Ringle, C.M., Henseler, J. and Hair, J.F. (2014), "On the emancipation of PLS-SEM: a commentary on rigdon (2012)", Long Range Planning, Vol. 47 No. 3, pp. 154-160.

Sawyerr, E. and Harrison, C. (2019), "Developing resilient supply chains: lessons from high-reliability organisations", Supply Chain Management: An International Journal, Vol. 25 No. 1, pp. 77-100.

Scholten, K. and Fynes, B. (2017), "Risk and uncertainty management for sustainable supply chains", Sustainable Supply Chains, Springer, Cham, pp. 413-436.

Scholten, K., Stevenson, M. and van Donk, D.P. (2019a), "Dealing with the unpredictable: supply chain resilience", International Journal of Operations and Production Management, Vol. 40 No. 1, pp. 1-10.

Scholten, K., Scott, P.S. and Fynes, B. (2019b), "Building routines for non-routine events: supply chain resilience learning mechanisms and their antecedents", Supply Chain Management: an International Journal, Vol. 24 No. 3, pp. 430-442.

Shastri, A., Singh, S.R., Yadav, D. and Gupta, S. (2014), "Supply chain management for two-level trade credit financing with selling price dependent demand under the effect of preservation technology", International Journal of Procurement Management, Vol. 7 No. 6, p. 695.

Sheffi, Y. and Rice, J.B. (2005), "A supply chain view of the resilient enterprise", MIT Sloan Management Review, Vol. 47 No. 1, p. 41.

Siawsh, N., Peszynski, K., Young, L. and Vo-Tran, H. (2019), "Exploring the role of power on procurement and supply chain management systems in a humanitarian organisation: a sociotechnical systems view", International Journal of Production Research, Vol. 59 No. 12, pp. 3591-3616.

Singh, R.K., Gupta, A. and Gunasekaran, A. (2018), "Analysing the interaction of factors for resilient humanitarian supply chain”, International Journal of Production Research, Vol. 56 No. 21, pp. 6809-6827.

Srinivasan, R. and Swink, M. (2018), "An investigation of visibility and flexibility as complements to supply chain analytics: an organizational information processing theory perspective", Production and Operations Management, Vol. 27 No. 10, pp. 1849-1867.

Stevenson, M. and Spring, M. (2007), "Flexibility from a supply chain perspective: definition and review", International Journal of Operations and Production Management, Vol. 27 No. 7, pp. 685-713.

Stewart, M. and Ivanov, D. (2019), "Design redundancy in agile and resilient humanitarian supply chains", Annals of Operations Research, pp. 1-27.

Stone, J. and Rahimifard, S. (2018), "Resilience in agri-food supply chains: a critical analysis of the literature and synthesis of a novel framework", Supply Chain Management, Vol. 23 No. 3, pp. 207-238.

Sudman, S. (1983), Applied Sampling, 4th ed., Academic Press, New York, NY.

Sutcliffe, K.M. (2011), "High reliability organizations (HROs)", Best Practice and Research: Clinical Anaesthesiology, Vol. 25 No. 2, pp. 133-144.

Swanson, E.B. and Ramiller, N.C. (2004), "Innovating mindfully with information technology", MIS Quarterly, Vol. 28 No. 4, pp. 553-583.

Teece, D.J., Pisano, G. and Shuen, A. (1997), "Dynamic capabilities and strategic management", Strategic Management Journal, Vol. 18 No. 7, pp. 509-533.

Tendall, D.M., Joerin, J., Kopainsky, B., Edwards, P., Shreck, A., Le, Q.B., Kruetli, P., Grant, M. and Six, J. (2015), "Food system resilience: defining the concept", Global Food Security, Vol. 6, pp. 17-23. 
IJOPM 41,9

Trkman, P., McCormack, K., de Oliveira, M.P.V. and Ladeira, M.B. (2010), "The impact of business analytics on supply chain performance”, Decision Support Systems, Vol. 49 No. 3, pp. 318-327.

Tukamuhabwa, B.R., Stevenson, M., Busby, J. and Zorzini, M. (2015), "Supply chain resilience: definition, review and theoretical foundations for further study", International Journal of Production Research, Vol. 53 No. 18, pp. 5592-5623.

Urbach, N. and Ahlemann, F. (2010), "Structural equation modeling in information systems research using partial least squares", Journal of Information Technology Theory and Application, Vol. 11 No. 2, pp. 5-40.

Van der Vegt, G., Essens, P., Wahlstrom, M. and George, G. (2015), "Managing risk and resilience: from the editors", Academy of Management Journal, Research Collection Lee Kong Chian School of Business, Vol. 58 No. 4, pp. 971-980.

Van Wassenhove, L.N. (2006), "Blackett memorial lecture. Humanitarian aid logistics: supply chain management in high gear", Journal of the Operational Research Society, Vol. 57 No. 5 , pp. 475-89.

Vanpoucke, E. and Ellis, S.C. (2019), "Building supply-side resilience - a behavioural view", International Journal of Operations and Production Management, Emerald Publishing Limited, Vol. 40 No. 1, pp. 11-33.

Vidgen, R., Shaw, S. and Grant, D.B. (2017), "Management challenges in creating value from business analytics", European Journal of Operational Research, Vol. 261 No. 2, pp. 626-639.

Vogus, T.J. and Sutcliffe, K.M. (2012), "Organizational mindfulness and mindful organizing: a reconciliation and path forward", Academy of Management Learning and Education, Vol. 11 No. 4, pp. 722-735.

Voorhees, C.M., Brady, M.K., Calantone, R. and Ramirez, E. (2016), "Discriminant validity testing in marketing: an analysis, causes for concern, and proposed remedies", Journal of the Academy of Marketing Science, Vol. 44 No. 1, pp. 119-134.

Waller, M.A. and Fawcett, S.E. (2013), "Data science, predictive analytics, and big data: a revolution that will transform supply chain design and management", Journal of Business Logistics, Vol. 34 No. 2, pp. 77-84.

Weick, K.E. and Sutcliffe, K.M. (2006), "Mindfulness and the quality of organizational attention", Organization Science, Vol. 17 No. 4, pp. 514-524.

Weick, K.E., Sutcliffe, K.M. and Obstfeld, D. (1999), "Organizing for high reliability: processes of collective mindfulness, Research in organizational behaviour", Research in Organizational Behavior, Vol. 24 No. 1, pp. 81-123.

Weick, K.E., Sutcliffe, K.M. and Obstfeld, D. (2005), "Organizing and the process of sensemaking”, Organization Science, Vol. 16 No. 4, pp. 409-421.

Weick, K., Sutcliffe, K. and Obstfeld, D. (2008), "Organizing for high reliability: processes of collective mindfulness”, Research in Organizational Behavior, Vol. 1 No. 1, pp. 1-38.

Wildgoose, N., Brennan, P. and Thompson, S. (2012), "Understanding your supply chain to reduce the risk of supply chain disruption", Journal of Business Continuity and Emergency Planning, Vol. 6 No. 1 , pp. 55-67.

Wolf, M., Vykoukal, J. and Beck, R. (2009), "Innovating mindfully with service-oriented grids- the role of organizational mindfulness in turbulent environments", DIGIT 2009 Proceedings, available at: http://aisel.aisnet.org/digit2009/6.

Wolf, M., Beck, R. and Pahlke, I. (2012), "Mindfully resisting the bandwagon: reconceptualising IT innovation assimilation in highly turbulent environments", Journal of Information Technology, Vol. 27 No. 3, pp. 213-235.

World Health Organization (2019), "Health emergency and disaster risk management framework", available at: https://apps.who.int/iris/bitstream/handle/10665/326106/9789241516181-eng.pdf (accessed 26 June 2021). 
Wycisk, C., McKelvey, B. and Hülsmann, M. (2008), "Smart parts' supply networks as complex adaptive systems: analysis and implications", International Journal of Physical Distribution and Logistics Management, Emerald Publishers, Vol. 38 No. 2, pp. 108-125.

Yu, W., Chavez, R., Jacobs, M., Wong, C.Y. and Yuan, C. (2019), "Environmental scanning, supply chain integration, responsiveness, and operational performance: an integrative framework from an organizational information processing theory perspective", International Journal of Operations and Production Management, Vol. 39 No. 5, pp. 787-814.

\section{About the authors}

Dr. Denis Dennehy is a Lecturer in Business Information Systems and funded Investigator with Lero | The Science Foundation Ireland Research Center for Software at NUI Galway, Ireland. His research primarily focuses on the mediating role of digital technologies and analytics in the context of information systems and its implications for people, organizations and society. His research has been published in leading journals, including the European Journal of Operational Research, International Journal of Production Research, Information Systems Frontiers, Information and Management, Information Technology and People, Journal of Systems and Software, and IEEE Software. He is a Senior Editor of Information Technology and People, holds conference chair of I3E2021 and lead guest editor of numerous special issues. Denis Dennehy is the corresponding author and can be contacted at: Denis.dennehy@nuigalway.ie

Dr. John Oredo is a Lecturer in Information Science and Management Science at the University of Nairobi, Kenya. His research interests lie primarily in data analytics and information technology (IT) project management, encompassing big data analytics, machine learning, cloud computing and structural equation modeling techniques. His research has been published in leading international journals and conferences, including the African Journal of Information Systems, IEEE Explore and the Americas Conference on Information Systems. He is currently the President of the Association of Information Systems of East Africa and is a reviewer for ranked journals such as Information Technology and People and other information systems (IS)-related journals.

Dr. Konstantina Spanaki is an Associate Professor at Audencia Business School in France and a Visiting Fellow at Centre for Information Management at Loughborough University, UK. Her work focuses on the intersection of information systems (IS) and operations management (OM). Recently, she is actively involved in projects related to data and information management, technology management, data sharing, cloud computing and biomimetic technologies. Konstantina's research has been published in various IS/OM outlets. She has served as Guest Editor for Special Issues in Production Planning and Control (PPC) and the International Journal of Production Research (IJPR). Konstantina also is an Association for Information Systems (AIS) and EurOMA member and has served the AIS community as both AE and a reviewer.

Dr. Stella Despoudi is a Lecturer in Operations and Supply Chain Management at Aston Business School, Aston University, UK. Stella's research expertise lies in the following research areas: food supply chain sustainability and resilience, food waste and food sustainability, circular economy and Industry 4.0. She has been the Lead Investigator in research projects related to food supply chain management such as "Sustainability, Resilience, and the Impact of Industry 4.0 in the Food Supply Chain." Stella's previous work has been published in journals such as Production Planning and Control, Annals of Operations Research, International Journal of Production Research and International Journal of Information Management.

Mike Fitzgibbon has an industrial background in engineering and information systems. Mike worked in the mid-1990s in international development in Tanzania. He followed this with work in the area of antiracism and interculturalism with the Irish Higher Education Equality Unit and in the area of food security with the International Famine Center (later the Center for Sustainable Livelihoods) in University College Cork (UCC). In 2006, he began his current role as a Lecturer in UCC in the areas of conflict, gender, humanitarian responses and communications. His current research interests include the media, conflict and development; Information and Communications Technologies (ICTs) in development; and the ethics-development-technology nexus.

For instructions on how to order reprints of this article, please visit our website: www.emeraldgrouppublishing.com/licensing/reprints.htm Or contact us for further details: permissions@emeraldinsight.com
Supply chain resilience 